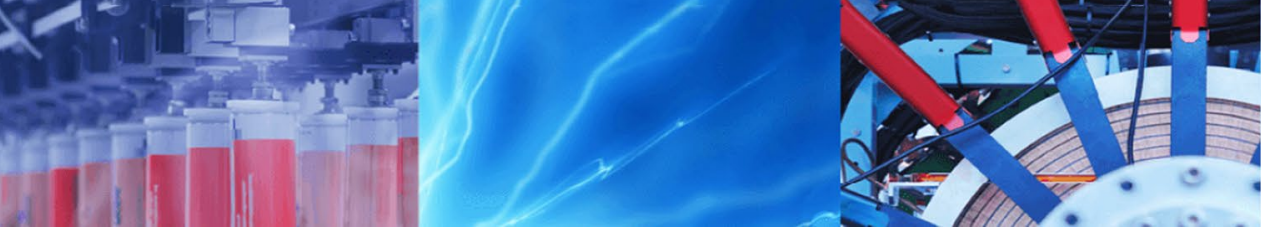

Research Article

\title{
Partial replacement of cement with granular marble residue: effects on the properties of cement pastes and reduction of $\mathrm{CO}_{2}$ emission
}

\author{
Tatiane Santos $^{1} \cdot$ Jardel P. Gonçalves ${ }^{2,3} \cdot$ Heloysa M. C. Andrade ${ }^{1,3}$
}

Received: 8 May 2020 / Accepted: 19 August 2020 / Published online: 31 August 2020

(c) Springer Nature Switzerland AG 2020

\begin{abstract}
The effects of CP V Portland cement replacement with granular marble residues were investigated. The physical-chemical properties of the starting materials and of the pastes were characterized by XRD, XRF, TG/DTA, SEM and granulometric analyses. Axial compressive strength, apparent density, capillary and total capacity of water absorption of the hardened pastes with $0,10,20$ and $30 \%$ replacements, aged for 28 days, were characterized. The results indicated that the partial replacement by the marble residue did not affect the cement hydration but provided packaging improvements and some filler action. The reduction of $\mathrm{CO}_{2}$ emission was estimated as 0.28 million tons per year due to replacement of $10 \%$ CP V Portland cement with the marble residue. The results indicated that this is an alternative means to reduce the $\mathrm{CO}_{2}$ emissions in the cement industry and to reuse marble residues that otherwise could be inadequately disposed.
\end{abstract}

Keywords Cement replacement $\cdot$ Marble residue $\cdot$ Filler $\cdot$ Packing effect $\cdot \mathrm{CO}_{2}$ emission $\cdot$ Sustainability

\section{Introduction}

The cement industry, one of the largest sources of atmospheric pollutants in the world, has been heavily charged by environmental control agencies for emitting huge amounts greenhouse gases [1]. Carbon dioxide emissions currently represent the major environmental concern of the cement industry, which accounts for about $5 \%$ of the global anthropogenic $\mathrm{CO}_{2}$ emissions [2]. In addition, the cement industry is responsible for consuming large amounts of non-renewable natural resources and electricity, which makes it an important source of environmental impacts.

Along with the accelerated development of civil construction, emission levels of pollutants are expected to increase and, therefore, strategic actions are necessary in order to make the cement production more sustainable. In this scenario, the use of mineral wastes in cement production is envisaged as a promising alternative since it also contributes to reduce the energy consumption and the environmental impacts, by promoting the reuse of mining wastes and providing an environmentally friendly destination for them $[3,4]$. The use of mineral wastes as additives in cementitious materials may improve the technical characteristics of the final product by modifying the internal structure of the matrix, increasing the durability and resistance, reducing the porosity of the capillary, reducing the fissures of thermal origin, etc. [5].

Brazil is one of the main producers of ornamental rocks in world, and the processing industry produces around of $1,610,000 \mathrm{t}$ of residues per year [6], corresponding to nearly $30 \%$ of the processed raw material [7]. Due to high costs, large amounts of these residues are inadequately disposed, causing important environmental and health impacts $[8,9]$.

$\triangle$ Heloysa M. C. Andrade, handrade@ufba.br | ${ }^{1}$ Laboratório de Catálise e Materiais, Departamento de Química Geral e Inorgânica, Instituto de Química, Rua Barão de Jeremoabo, 147, Campus de Ondina, Salvador, BA 40170-280, Brazil. 2Escola Politécnica, Departamento de Construção e Estruturas, Universidade Federal da Bahia, Rua Prof. Aristides Novis, nº 02, Bairro Federação, Salvador, BA 40210-630, Brazil. ${ }^{3}$ Centro Interdisciplinar de Energia e Ambiente (CiEnAm), Campus de Ondina, Salvador, BA 40170-115, Brazil. 
Marble, one of the main ornamental stone rocks, is a metamorphic rock mainly composed by calcite $\left(\mathrm{CaCO}_{3}\right)$ and dolomite $\left(\mathrm{CaCO}_{3} \cdot \mathrm{MgCO}_{3}\right)$ and smaller amounts of clay minerals, micas, quartz, pyrite, iron oxides, muscovite and biotite [10]. Thus, the reuse of the marble residue seems to be useful to mitigate the environmental impacts of the production chain of ornamental rocks, for example, as cement additions or replacements.

The use of marble waste as a partial cement replacement has been investigated aiming at the production of alternative building materials, such as concretes, mortars or pastes [11-13]. However, marble residue is generally used after grinding, so that finely divided particles can act as a filler in cement matrices. This physical action of marble residues has been described as packaging effects related to the size of the particles, in addition to the nucleation mechanism promoted by the smaller particles that lodge in the interstices of the clinker crystals and, consequently, promoting the filler effect [14].

On the other hand, several authors [14-16] reported that the marble residue played a chemical role in the hydration reactions of the cement. This performance is due to the reaction between calcium carbonate $\left(\mathrm{CaCO}_{3}\right)$ and tricalcium silicate $\left(C_{3} A\right)$, which can lead to the formation of hydrated calcium monocarboaluminate $\left(\mathrm{Ca}_{4} \mathrm{Al}_{2}\left(\mathrm{CO}_{3}\right)\right.$ $\left.(\mathrm{OH})_{12} \cdot 5 \mathrm{H}_{2} \mathrm{O}\right)$ and/or hydrated calcium hemicarboaluminate $\left(\mathrm{Ca}_{4} \mathrm{Al}_{2}\left(\mathrm{CO}_{3}\right) 0.5(\mathrm{OH})_{13} \cdot 5.5 \mathrm{H}_{2} \mathrm{O}\right)$, which have binding properties and lead to increased compressive strength [16]. The reaction is favored; the higher are the $C_{3} A$ content of the cement, the specific surface area and the fineness of the residue [17]. The reaction also leads to the modification of the equilibrium of the hydration reactions, reducing the precipitation of monosulfate and favoring ettringite formation [18].

The milling of the replacement materials, such as residue, ash and slag, generally involves energy consumption, increases the number of processes and costs and contributes to $\mathrm{CO}_{2}$ emissions during the production of cementitious materials. Herein, a granular marble residue was used without any previous treatment. The physical-chemical and mechanical effects of the partial replacement of cement with white marble granular residue in cement pastes were studied, and the impact of the cement replacement on the reduction of $\mathrm{CO}_{2}$ emissions in the cement industry, civil construction and in the aggregate industry was estimated.

\section{Materials and methods}

\subsection{Starting materials}

A rapid hardening and high initial resistance Portland cement (PC), known as "CPV" under the Brazilian standards
[19], was chosen for this study. This type of cement is similar to the rapid hardening Portland cement (RHPC) [20] and presents chemical composition comparable to the common Portland cement. In addition, this cement presents low content of clinker replacement by carbonate material (defined as containing: $95 \% \leq$ clinker + gypsum $\leq 100 \%$; and $0 \%<$ filler $<5 \%$, by mass), high contents of hydrated calcium silicates and greater fineness than other types of cement. Such properties allow the evaluation of a waste material as pozzolanic, cementitious or non-reactive, without interference of the constituent materials of the cement.

The marble residue (MR), a granular residue of heterogeneous particle size distribution, was obtained from a marble processing industry located in Bahia, Brazil. The sample was collected according to ASTM E300-03 [21], and in order to reduce the processing costs in a possible application, the residue was used without any previous treatment for the experiments.

\subsection{Cement pastes}

After weighing, the raw materials were mixed in a hermetically sealed plastic bag to thoroughly mix the solid particles before the paste preparation the paste preparation.

The cement pastes were prepared using a constant speed mixer (Chandler model 3260) such that the marble waste contents in the cement pastes were $0,10,20$ and $30 \%$ of the cement weight and the water/cement factor was 0.4. After preparation, the pastes were stored in hermetically sealed packages and, after 28 days aging, they were ground to obtain fine powders that were subsequently characterized by different techniques. These pastes were also molded as trapezoidal specimens of $14 \times 12 \times 11 \mathrm{~mm}$, stored in hermetically sealed packages for 28 days and used for the apparent density testing. New cement pastes were further prepared according to ASTM C39 [22], molded in $5 \times 10 \mathrm{~cm}$ cylindrical specimens and used for mechanical and physical characterization by capillary absorption and total absorption of water. The molded pastes were aged for 3 and 28 days before resistance testing while those used in the absorption tests were aged for 28 days. The pastes were named according to the marble waste content; for example, 10MR indicates a cement replacement by $10 \% \mathrm{MR}$. The mixtures used for the preparations are presented in Table 1.

\subsection{Experimental procedures}

\subsubsection{Physical-chemical characterization}

The chemical composition of the samples was obtained using a Bruker-XRF S8-Tiger X-ray Fluorescence 
Table 1 Preparation of the cement pastes

\begin{tabular}{llll}
\hline $\begin{array}{l}\text { MR content } \\
(\%)\end{array}$ & PC (g) & MR (g) & Water $(\mathrm{g})$ \\
\hline 0 & $875.0 \pm 0.5 \mathrm{~g}$ & - & $350.0 \pm 0.5 \mathrm{~g}$ \\
10 & $787.5 \pm 0.5 \mathrm{~g}$ & $87.5 \pm 0.5 \mathrm{~g}$ & $315.0 \pm 0.5 \mathrm{~g}$ \\
20 & $700.0 \pm 0.5 \mathrm{~g}$ & $175.0 \pm 0.5 \mathrm{~g}$ & $280.0 \pm 0.5 \mathrm{~g}$ \\
30 & $612.5 \pm 0.5 \mathrm{~g}$ & $262.5 \pm 0.5 \mathrm{~g}$ & $245.0 \pm 0.5 \mathrm{~g}$ \\
\hline
\end{tabular}

Spectrometer, and the Bogue equation [23] was applied to assess mineralogical composition of the cement from the obtained chemical composition.

The mineralogical composition was determined using a Shimadzu-XRD 6000 Powder Diffractometer.

A micromeritics AccuPyc II 1340 Helium Pycnometer was used to determine the specific mass of the materials. The surface area of the starting materials was determined using the BET method in a Micromeritics ASAP 2020 equipment.

The granulometric analysis of $P C$ was performed in a Malvern, Mastersizer 3000, with an AERO S accessory for dry analysis, while the MR sample was characterized using a sieving method adapted from the ASTM D6913 [24].

The morphological characterization of the samples was carried out on a Hitachi model S-3400 N SEM microscope.

Thermal analyses of the materials were carried out on a Shimadzu DTG $60 \mathrm{H}$ equipment, following the methodology developed by Dweck et al. [25].

\subsubsection{Physical and mechanical characterization}

The axial compressive strength tests of the cement pastes were carried out according to the criteria of ASTM C39 [22]. Three test specimens of each paste were produced which, before testing, were subjected to $24 \mathrm{~h}$ wet curing, demolded and then cured in water up to the test ages of 3 and 28 days. The resistance was calculated using the average force obtained from each triplicate and Eq. (1):

$\mathrm{Fc}=\frac{F}{\pi \times r^{2}}$

where $\mathrm{Fc}$ is the axial compressive strength, $\mathrm{MPa}$; $\mathrm{F}$ the average of the maximum forces obtained per test, $\mathrm{N}$; and $\mathrm{r}$ the radius of the test piece, $\mathrm{mm}$.

The apparent density of the hardened pastes was determined according to ASTM C127-15 [26] and calculated using Eq. (2).

$d_{\mathrm{a}}=\frac{m_{\mathrm{s}}}{m_{\mathrm{sat}}-m_{\mathrm{a}}}$ where $d_{\mathrm{a}}$ is the apparent density $\left(\mathrm{g} / \mathrm{cm}^{3}\right) ; m_{\mathrm{s}}$ the mass of the oven dried sample between 105 and $110^{\circ} \mathrm{C}(\mathrm{g}) ; m_{\text {sat }}$ the mass of test specimen saturated with water $(g) ; m_{\mathrm{a}}$ the mass of test specimen immersed in water $(\mathrm{g})$.

The capillary water absorption test was performed according to ASTM C1585-04 [27]. The water absorption by capillarity was calculated by dividing the mass increase by the cross-sectional area of the surface of the test piece in contact with the water, for different test times, according to Eq. (3)

$C=\frac{A-B}{S}$

where $C$ is the water absorption by capillarity at a definite time interval $\left(\mathrm{g} \mathrm{cm}^{-2}\right)$; $A$ the mass of the sample piece that remained with one of the faces in contact with water for each of time interval ( $\mathrm{g}$ ); $B$ the mass of the dry sample piece $(\mathrm{g}) ; S$ the cross-sectional area of the sample face in contact with water $\left(\mathrm{cm}^{2}\right)$.

The total water absorption capacity test was performed according to the ASTM C642-13 [28] after 28 days of immersion of the test specimens, and the total absorption capacity was calculated using Eq. (4).

$A_{\mathrm{T}}=\frac{\left(m_{\mathrm{sat}}-m_{\mathrm{s}}\right)}{m_{\text {sat }}} \times 100$

where $A_{T}$ is the total water absorption after 28 days of wet curing (\%); $m_{\text {sat }}$ the mass of test specimen saturated with water $(\mathrm{g}) ; m_{\mathrm{s}}$ the mass of the oven dried sample at $105-110^{\circ} \mathrm{C}(\mathrm{g})$.

\subsection{Evaluation of the $\mathrm{CO}_{2}$ emission reduction in the cement industry due to the use of the marble residue (MR) replacements}

The methodology proposed by the Intergovernmental Panel on Climate Change $[29,30]$ was used to estimate the $\mathrm{CO}_{2}$ emissions due to the cement production in Brazil in 2018, as described in Eq. (5). The calculation considers that the $\mathrm{CO}_{2}$ emission during the Portland cement production is associated with both the limestone calcination and the energy consumption involved in the combustion processes. The $\mathrm{CO}_{2}$ emission from the electricity generation is not considered since most of the energy in Brazil is produced by hydroelectric power plants, with no relevant contribution for the $\mathrm{CO}_{2}$ emissions [31].

$$
\begin{aligned}
E_{\text {Cement }}= & \left(K_{\mathrm{c}} \cdot \mathrm{CaO}_{\text {Clinker }} \cdot \text { Clinquer }_{\text {Cement }} \cdot \mathrm{PC}\right) \\
& +\left(\sum_{\mathrm{b}} C_{\mathrm{b}} \cdot \mathrm{ConFaC}_{\mathrm{b}} \cdot \mathrm{EmF}_{\mathrm{b}}^{\mathrm{CO}_{2}} \cdot \mathrm{FCO}_{\mathrm{b}} \cdot K\right)
\end{aligned}
$$


where $E_{\text {Cement }}$ is the $\mathrm{CO}_{2}$ emission during the production of Portland cement (tonnes); $K_{\mathrm{C}}$ the constant equal to $0.785\left(\mathrm{~g} / \mathrm{mol} \mathrm{CO}_{2}\right) /(\mathrm{g} / \mathrm{mol} \mathrm{CaO}) ; \mathrm{CaO}_{\text {Clinker }}$ the (calcium oxide/clinker) ratio, equal to 0.65 ; Clinker Cement $_{\text {the (clinker/ }}$ cement) ratio, equal to 0.80 in Brazilian industry; PC the annual production of cement CP V (tons); $b$ the types of fuels used in the production of cement; $C_{b}$ the annual fuel $b$ consumption (1000 tep); ConFac $c_{\mathrm{b}}$ the conversion factor (TJ/1000 tep); $\mathrm{EmF}_{\mathrm{b}}^{\mathrm{CO}_{2}}$ the $\mathrm{CO}_{2}$ emission factor of fuel $b$ (tonnes of $\mathrm{C} / \mathrm{TJ}$ ); $\mathrm{FCO}_{\mathrm{b}}$ the fraction of oxidized carbon in the combustion process; $K$ the constant equal to $3.667 \mathrm{~g} /$ $\mathrm{mol}$ of $\left.\mathrm{CO}_{2}\right) /(\mathrm{g} / \mathrm{mol}$ of $\mathrm{C})$.

The $\mathrm{CO}_{2}$ emission factors of each fuel and the oxidized carbon fraction are given by the Intergovernmental Panel on Climate Change [1], while annual fuel consumption is given by the Brazilian Ministry of Mines and Energy [32].

Finally, the amount of marble residue produced in Brazil in 2018 was calculated from the rock production data [33] and considering that $30 \%$ of the processed material is discarded [7]. In this way, the use of this waste was evaluated as a strategy to reduce the $\mathrm{CO}_{2}$ emission reduction from the Portland cement production. It should be noted that as the marble residue was not ground, its use as a partial substitute for cement does not contribute to total $\mathrm{CO}_{2}$ emissions nor for energy consumption.

\section{Results and discussion}

\subsection{Characterization of the starting materials}

The physical and chemical characteristics of the marble residue (MR) and the cement (PC) are presented in Table 2.

$\mathrm{PC}$ was mainly composed of $\mathrm{CaO}$ and $\mathrm{SiO}_{2}$ and presented mineralogical composition and physical properties that agree with NBR 5733 [19]. On the other hand, the $\mathrm{MgO}$ content shown in Table 2 indicated that MR has a typical composition of a calcitic dolomite marble. According to ASTM C618-19 [34], to be useful as a pozzolanic material, a residue must meet some physical and chemical requirements such as: sum of $\mathrm{SiO}_{2}, \mathrm{Al}_{2} \mathrm{O}_{3}$ and $\mathrm{Fe}_{2} \mathrm{O}_{3}$ contents $\geq 70 \%, \mathrm{SO}_{3}$ content $\leq 4 \%$, loss on ignition $\leq 10 \%$ and amount of material retained in a sieve with mesh opening of $45 \mu \mathrm{m} \leq 34 \%$. Thus, the results shown in Table 2 indicated that the MR used in this study should not present pozzolanic properties. In addition, the small specific surface area of the marble residue (Table 2) was taken as another indication of poor pozzolanic activity, contributing to reduce the surface area of the cement paste and resulting in a lower absorption capacity and greater fluidity [35]. To be used as a filler addition, the residue must be finely milled with approximately the same fineness as the Portland cement [36] and the particles of the filler
Table 2 Chemical and physical properties of PC and MR

\begin{tabular}{lll}
\hline & $\mathrm{PC}$ & $\mathrm{MR}$ \\
\hline Chemical composition (\%) & & \\
$\mathrm{CaO}$ & 61.42 & 77.57 \\
$\mathrm{SiO}_{2}$ & 20.49 & 2.72 \\
$\mathrm{MgO}$ & 3.15 & 19.11 \\
$\mathrm{Al}_{2} \mathrm{O}_{3}$ & 3.13 & 0.11 \\
$\mathrm{Fe}_{2} \mathrm{O}_{3}$ & 0.08 & 0.30 \\
$\mathrm{SO}_{3}$ & - & 0.08 \\
$\mathrm{~K}_{2} \mathrm{O}$ & 0.99 & 0.02 \\
$\mathrm{Loss}_{\text {on ignition }(\%)}$ & 4.68 & 45.31 \\
$\mathrm{Mineralogical} \mathrm{composition}_{\mathrm{C}}$ & & \\
$\mathrm{C}_{3} \mathrm{~S}$ & 68.64 & - \\
$\mathrm{C}_{2} \mathrm{~S}$ & 6.98 & - \\
$\mathrm{C}_{3} \mathrm{~A}$ & 3.03 & - \\
$\mathrm{C}_{4} \mathrm{AF}$ & 9.54 & - \\
Physical properties & & \\
Specific mass $\left(\mathrm{g} / \mathrm{cm}^{3}\right)$ & 3.18 & 2.90 \\
Specific surface area-BET $\left(\mathrm{m}^{2} / \mathrm{g}\right)$ & 2.0 & $<1$ \\
Mean particle diameter $(\mu \mathrm{m})$ & 14.28 & 450 \\
\hline
\end{tabular}

Table 3 Granulometric analysis of the marble residue (MR)

\begin{tabular}{lll}
\hline Mesh & $\mu \mathrm{m}$ & $\begin{array}{l}\text { Retained } \\
\text { mass (\%) }\end{array}$ \\
\hline 14 & 1410 & 9.98 \\
35 & 500 & 49.93 \\
60 & 250 & 15.49 \\
100 & 150 & 9.62 \\
200 & 75 & 8.78 \\
$<200$ & $<75$ & 6.20 \\
$\begin{array}{l}\text { Mean diameter } \\
(\mu \mathrm{m})\end{array}$ & 450 \\
\hline
\end{tabular}

should have dimensions between 5 and $75 \mu \mathrm{m}$ [37]. From Table 2, it can be observed that the mean diameter of the MR particles was much larger than that of the PC particles. To further confirm this, the granulometric analysis of the marble residue is shown in Table 3, indicating a very heterogeneous grain size distribution.

Moreover, the observed differences in specific masses of PC and MR (Table 2) apparently did not contribute to decrease the bulk density of the cement pastes containing the marble residue.

The X-ray diffractograms of MR and PC are shown in Fig. 1.

The mineralogical analysis of $\mathrm{PC}$ indicated the main phases $\mathrm{C}_{2} \mathrm{~S}-2 \mathrm{CaO} \cdot \mathrm{SiO}_{2}$ (PDF \# 00-033-0302), $\mathrm{C}_{3} \mathrm{~S}-3 \mathrm{CaO} \cdot \mathrm{SiO}_{2}$ (PDF \# 00-003-0807), and Basanite (B) $-\mathrm{CaSO}_{4} \cdot 0.5 \mathrm{H}_{2} \mathrm{O}$ (PDF \# 00-003-0807) and $\mathrm{C}_{4} \mathrm{AF}-4 \mathrm{CaO} \cdot \mathrm{Al}_{2} \mathrm{O}_{3} \cdot \mathrm{Fe}_{2} \mathrm{O}_{3}$ (PDF\#01-074-0803). 
Fig. 1 X-ray powder diffractogram: $P C$ Portland cement CP V and $M R$ marble residue

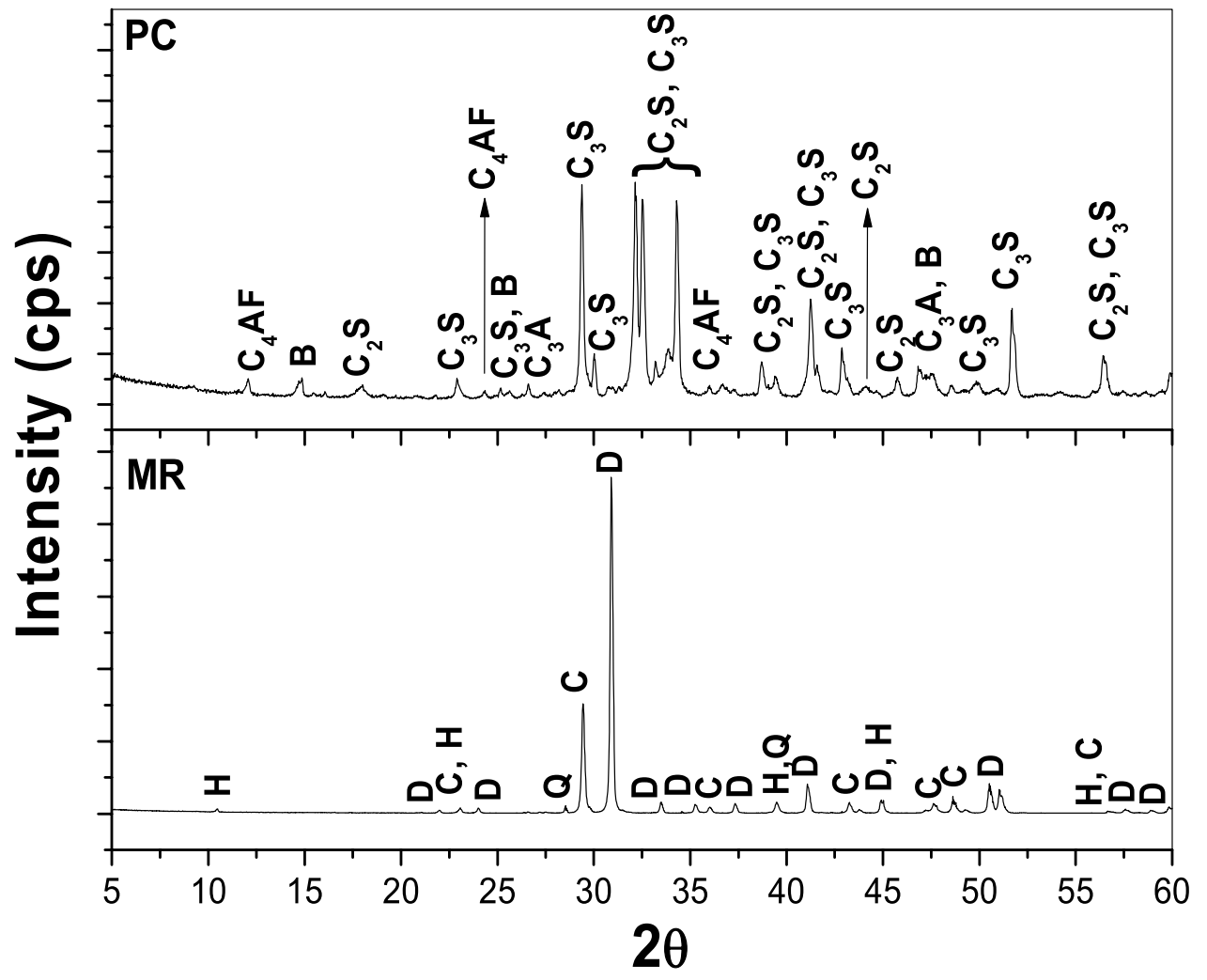

The crystalline phases found in MR were: calcite (C)$\mathrm{CaCO}_{3}$ (PDF \# 01-085-1108), dolomite (D)- CaMg $\left(\mathrm{CO}_{3}\right)_{2}$ (PDF \# 01-084-1208), hatrurite (H)- $\mathrm{Ca}_{3} \mathrm{SiO}_{5}$ (PDF \# 01-0732077) and quartz (Q) - $\mathrm{SiO}_{2}$ (PDF \# 01-079-1915). From Fig. 1 , it is observed that dolomite and calcite were the main crystalline minerals, as expected for a marble. The quartz and hatrurite phases were detected in less quantity, and the latter indicated that the marble residue may have binding properties, a desirable condition for cementbased products [38].

The TG/DTG and DTA results are, respectively, shown in Fig. 2.

Figure 2 shows total mass losses of $43.98 \%$ and $4.13 \%$ for $M R$ and $P C$, respectively, indicating that the cement was much more stable than the marble residue. It may be also observed that the only mass loss region, between 550 and $800^{\circ} \mathrm{C}$, of the TG curve of the marble residue was related to the simultaneous and endothermal decomposition of calcite and dolomite, as indicated in Eqs. (6) and (7).

$\mathrm{CaCO}_{3} \rightarrow \mathrm{CaO}+\mathrm{CO}_{2}$

$\mathrm{CaMg}\left(\mathrm{CO}_{3}\right)_{2} \rightarrow \mathrm{CaO}+\mathrm{MgO}+2 \mathrm{CO}_{2}$

The content of calcite and dolomite in MR was calculated using Eqs. (6) and (7) and the mass loss relative to the decomposition of these phases, according to Eq. (8).

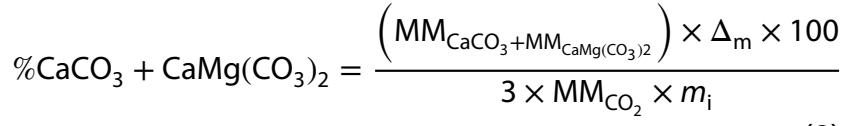

where $\mathrm{MM}_{\mathrm{CaCO}_{3}}$ is the $\mathrm{CaCO}_{3}$ molar mass (100.09); $\mathrm{MM}_{\mathrm{CaMg}\left(\mathrm{CO}_{3}\right)_{2}}$ the $\mathrm{CaMg}\left(\mathrm{CO}_{3}\right)_{2}$ molar mass (184.40); $\Delta_{\mathrm{m}}$ the mass loss due to decomposition of $\mathrm{CaCO}_{3}$ and $\mathrm{CaMg}\left(\mathrm{CO}_{3}\right)_{2}$ (4.92 mg); $\mathrm{MM}_{\mathrm{CO}_{2}}$ the $\mathrm{CO}_{2}$ molar mass $(44.01) ; m_{\mathrm{i}}$ the initial mass of the sample used in the analysis (11.32 $\mathrm{mg}$ ).

Consequently, the calculated content of $\mathrm{CaCO}_{3}+\mathrm{CaMg}\left(\mathrm{CO}_{3}\right)_{2}$ in MR corresponded to $93.65 \%$. It is known from the XRF results that the marble residue contained $19.11 \%$ of $\mathrm{MgO}$ and that the magnesium content of MR was incorporated to the $\mathrm{CaMg}\left(\mathrm{CO}_{3}\right)_{2}$ phase. Thus, it can be stated that MR contained $19.11 \%$ of $\mathrm{CaMg}\left(\mathrm{CO}_{3}\right)_{2}$ and $74.54 \%$ of $\mathrm{CaCO}_{3}$.

PC decomposition occurred as two small thermal events, one between 350 and $440{ }^{\circ} \mathrm{C}$, related to a slight hydration process, leading to the formation of $\mathrm{Ca}(\mathrm{OH})_{2}$, and another one, between 550 and $700{ }^{\circ} \mathrm{C}$, attributed to the decomposition of $\mathrm{CaCO}_{3}$. The thermal events related to the decomposition of both materials were endothermal, as shown in Fig. 2.

The SEM images of the marble residue are shown in Fig. 3.

The marble residue showed irregular particles of angular shape, probably due to the cutting/sawing process of 
Fig. 2 TG, DTG and DTA curves: $P C$ Portland cement CP V and $M R$ marble residue

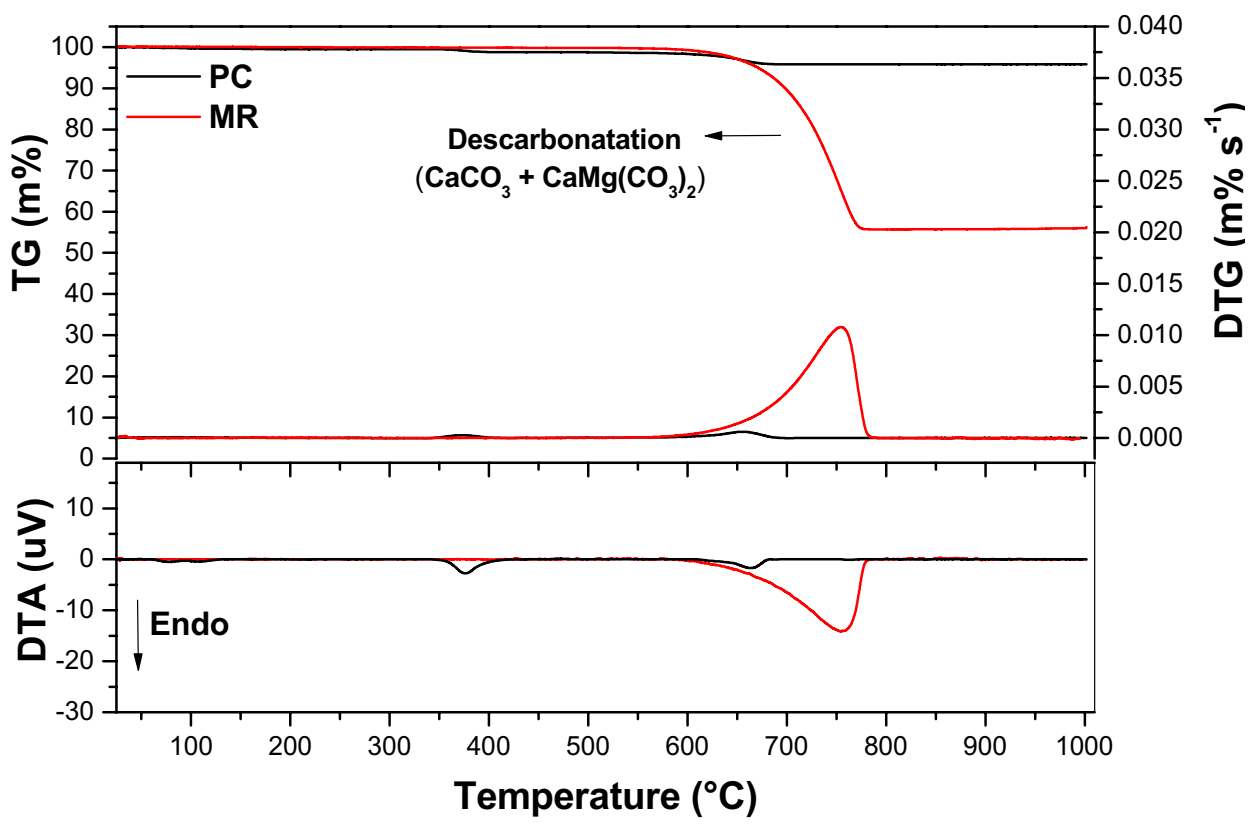

the ornamental rock blocks. The particles showed micrometric size, suggesting that the replacement in the cement paste can impart more cohesion. The particles also showed extensive cleavage planes characteristic of calcite, as indicated in Fig. 3 [39].

\subsection{Characterization of the cement pastes}

Figure 4 shows the X-ray diffractograms of the cement pastes containing $M R$, and from them the following phases were identified: calcite (C) (PDF\#01085-1108), $C_{2} S$ (PDF\#00-033-0302), $C_{4} A F$ (PDF\#01074-0803), $\mathrm{C}-\mathrm{A}-\mathrm{S}-\mathrm{H}-2 \mathrm{CaO} \cdot \mathrm{Al}_{2} \mathrm{O}_{3} \cdot \mathrm{SiO}_{2} \cdot 8 \mathrm{H}_{2} \mathrm{O}$ (PDF\#00-020-0212), C-S-H-3CaO-2SiO $2 \cdot(3+x) \mathrm{H}_{2} \mathrm{O}$ (PDF\#00-010-0374), dolomite (D) (PDF\#01-084-1208), ettringite (E)-3CaO $\cdot \mathrm{Al}_{2} \mathrm{O}_{3} \cdot 3 \mathrm{CaSO}_{4} \cdot 32 \mathrm{H}_{2} \mathrm{O}$ (PDF\#00-0020059), portlandite $(\mathrm{P})-\mathrm{Ca}(\mathrm{OH})_{2}$ (PDF\#00-004-0733) and quartz (Q) (PDF\#01-079-1915).

The TG/DTG and DTA curves obtained for the cement-marble pastes are shown in Fig. 5, and the assignment of the corresponding temperature ranges of decomposition of the phases in the cement pastes containing MR is shown in Table 4. The decomposition reactions occurring during the TG analysis of the cement pastes are well reported in the literature and are related to different temperature ranges. However, different samples and analytical procedures may shift the temperature range of the thermal events. Herein, the analyses were performed in a temperature range of $25-1000^{\circ} \mathrm{C}$, with a heating rate of $10^{\circ} \mathrm{C} \mathrm{min}^{-1}$, under $\mathrm{N}_{2}$
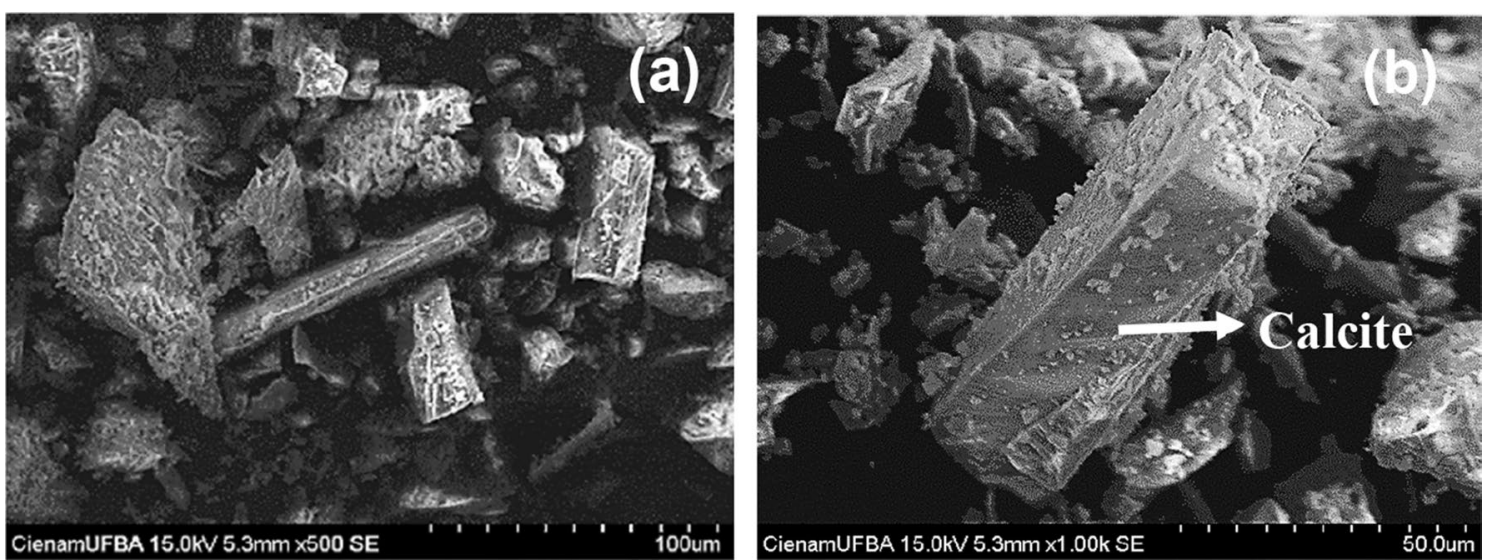

Fig. 3 SEM images of the marble residue (MR) with different amplifications a $500 \times$, b $1000 \times$ 
Fig. 4 X-ray powder diffractograms of cement pastes containing marble residue (MR)
Fig. 5 TG, DTG and DTA curves of cement pastes containing MR
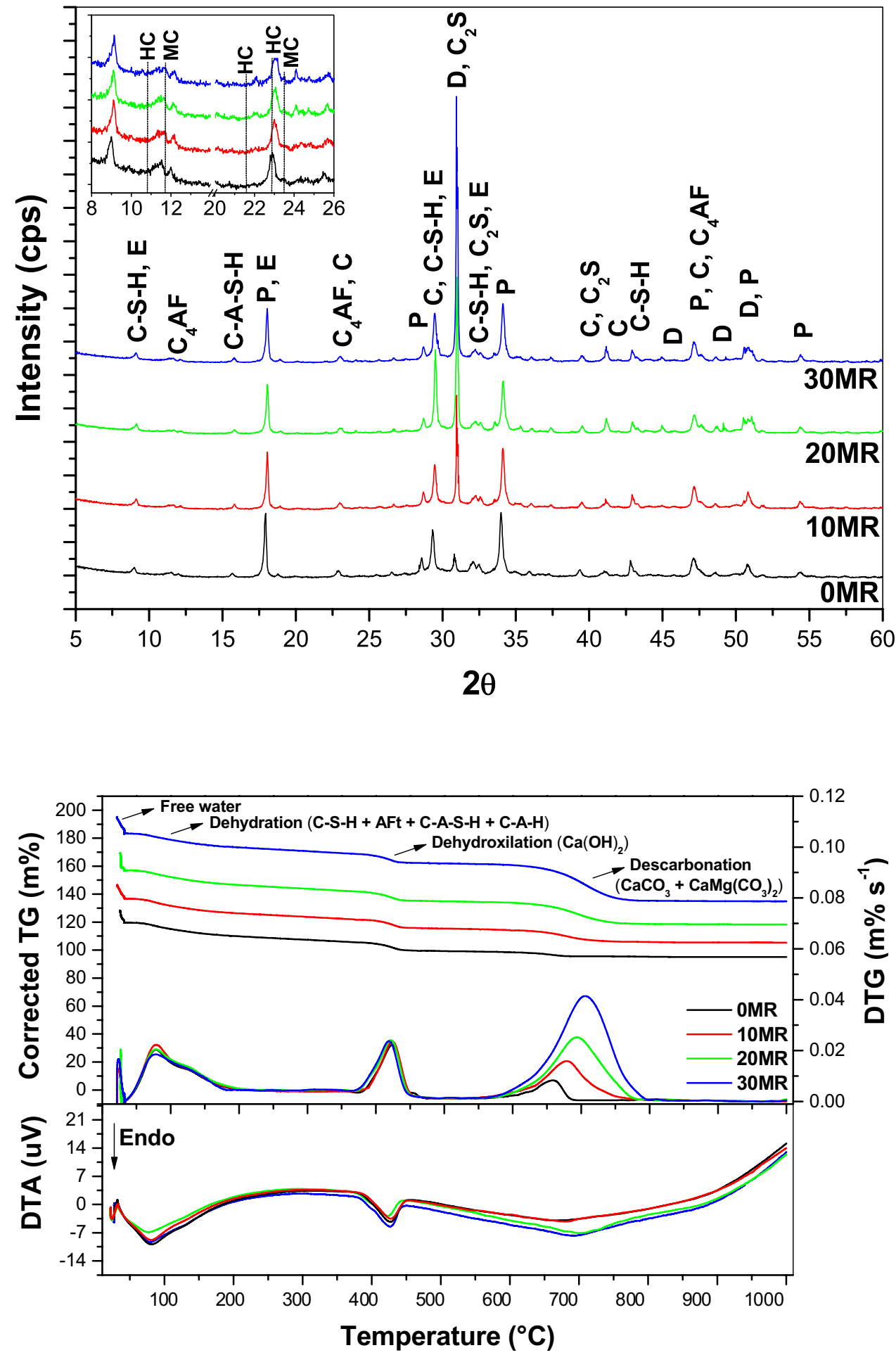

flow of $50 \mathrm{~mL} \mathrm{~min}{ }^{-1}$, with an initial isothermal step of $35^{\circ} \mathrm{C}$ for $1 \mathrm{~h}$. To confirm the reliability of the data, the obtained temperature ranges are also compared with those reported in the literature [40-46] in Table 5.

Based on the DTG curves of Fig. 5, the phases were quantified and are presented in Fig. 6 .
From the data presented in Fig. 6, the formation of the cement hydration products was not significantly affected by the marble replacements in the cement pastes. The contents of calcium hydroxide in the pastes remained nearly unchanged, indicating that the marble residue did not act as a pozzolan and no chemical action could be observed. 
As expected, the mass loss due to the decomposition of the carbonates increased with the increase in the marble replacement in the paste, since marble is a carbonate rock.

Thus, the mineralogical data obtained by TG/DTG were consistent with those obtained by XRD and XRF, and the expected and experimental carbonate contents are further compared in Table 6.
Table 4 Assignment of the temperature ranges of decomposition of the phases in the cement pastes from Fig. 5-TG-DTG/DTA

\begin{tabular}{lll}
\hline$T\left({ }^{\circ} \mathrm{C}\right)$ & Phase & Reaction \\
\hline $35^{\circ}-180^{\circ}$ & $\mathrm{CSH}$ & $3 \mathrm{CaO} \cdot 2 \mathrm{SiO} \cdot x \mathrm{H}_{2} \mathrm{O} \rightarrow 3 \mathrm{CaO} \cdot 2 \mathrm{SiO}+x \mathrm{H}_{2} \mathrm{O}$ \\
& $\mathrm{CFt}$ & $3 \mathrm{CaO} \cdot \mathrm{Al}_{2} \mathrm{O}_{3} \cdot 3 \mathrm{CaSO} \mathrm{CH}_{4} \cdot x \mathrm{H}_{2} \mathrm{O} \rightarrow 3 \mathrm{CaO} \cdot \mathrm{Al}_{2} \mathrm{O}_{3} \cdot 3 \mathrm{CaSO}_{4}+x \mathrm{H}_{2} \mathrm{O}$ \\
$180-350$ & $\mathrm{C}-\mathrm{A}-\mathrm{S}-\mathrm{H}$ & $2 \mathrm{CaO} \cdot \mathrm{Al}_{2} \mathrm{O}_{3} \cdot \mathrm{SiO}_{2} \cdot y \mathrm{H}_{2} \mathrm{O} \rightarrow 2 \mathrm{CaO} \cdot \mathrm{Al}_{2} \mathrm{O}_{3} \cdot \mathrm{SiO}_{2}+y \mathrm{H}_{2} \mathrm{O}$ \\
& $\mathrm{C}-\mathrm{A}-\mathrm{H}$ & $4 \mathrm{CaO} \cdot \mathrm{Al}_{2} \mathrm{O}_{3} \cdot 2 \mathrm{ZH}_{2} \mathrm{O} \rightarrow 4 \mathrm{CaO} \cdot \mathrm{Al}_{2} \mathrm{O}_{3}+z \mathrm{H}_{2} \mathrm{O}$ \\
$350-465$ & $\mathrm{CH}$ & $\mathrm{Ca}(\mathrm{OH})_{2} \rightarrow \mathrm{CaO}+\mathrm{H}_{2} \mathrm{O}$ \\
$500-800$ & $\mathrm{CaCO}$ & $\mathrm{CaCO} \rightarrow \mathrm{CaO}+\mathrm{CO}_{2}$ \\
$500-800$ & $\mathrm{CaMg}_{3}$ & $\mathrm{CaMg}\left(\mathrm{CO}_{3}\right)_{2} \rightarrow \mathrm{CaO}+\mathrm{MgO}+2 \mathrm{CO}_{2}$ \\
\hline
\end{tabular}

\begin{tabular}{llllllll}
\hline Phase & \multicolumn{7}{l}{ Decomposition temperature ranges $\left({ }^{\circ} \mathrm{C}\right)$} \\
\cline { 2 - 8 } & {$[40]$} & {$[41]$} & {$[42]$} & {$[43]$} & {$[44]$} & {$[45]$} & {$[46]$} \\
\hline $\mathrm{CSH}$ & $<160$ & $35-200$ & $38-180$ & $<200$ & $90-110$ & $100-150$ & $87-210$ \\
$\mathrm{AFt}$ & & & & & & & \\
$\mathrm{C}-\mathrm{A}-\mathrm{S}-\mathrm{H}$ & $160-220$ & $200-350$ & $180-240$ & - & - & - & - \\
$\mathrm{C}-\mathrm{A}-\mathrm{H}$ & & & & & & & \\
$\mathrm{CH}$ & $390-540$ & $350-500$ & $350-450$ & $450-550$ & $420-450$ & $450-520$ & $419-564$ \\
$\mathrm{CaCO}_{3}$ & $700-780$ & $500-800$ & $550-750$ & $750-900$ & $650-700$ & $650-800$ & $668-814$ \\
\hline
\end{tabular}

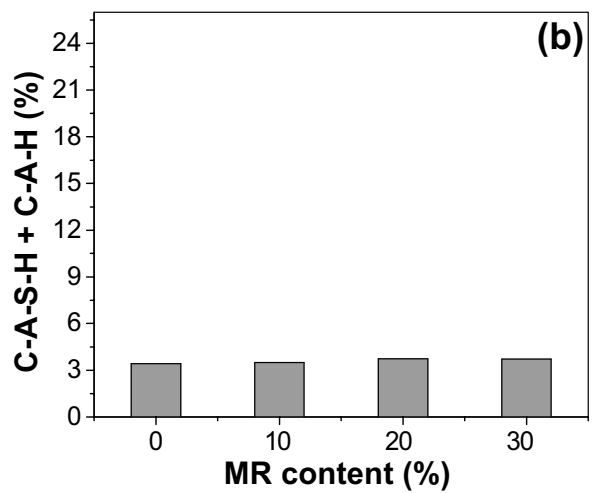

Fig. 6 Phase composition of cement pastes containing MR as determined by DTG
Table 5 Decomposition temperature ranges of the hydrated cement phases obtained by TG analyses reported in Ref. [40-46]
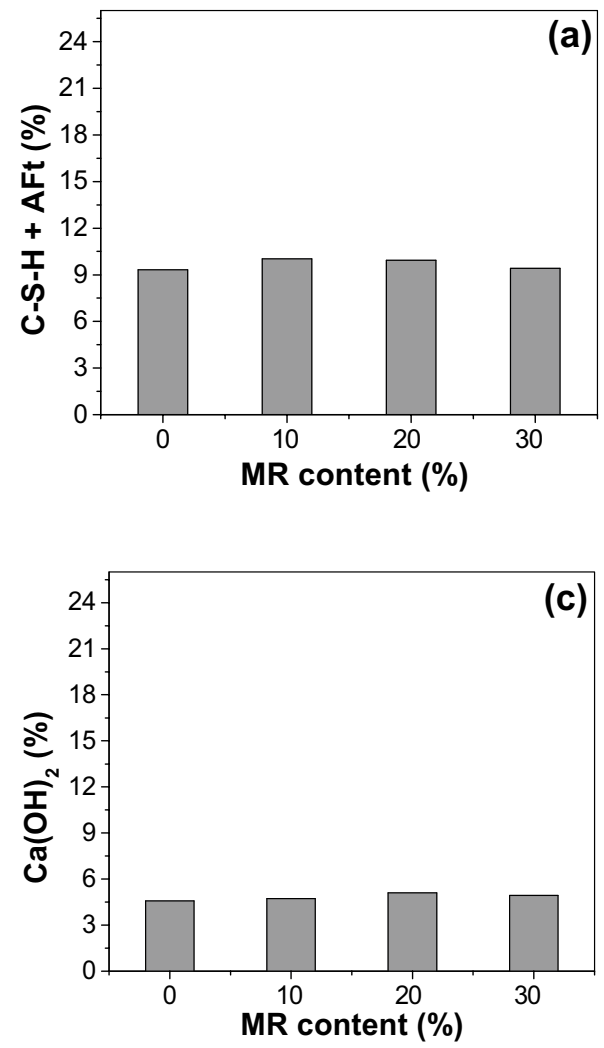

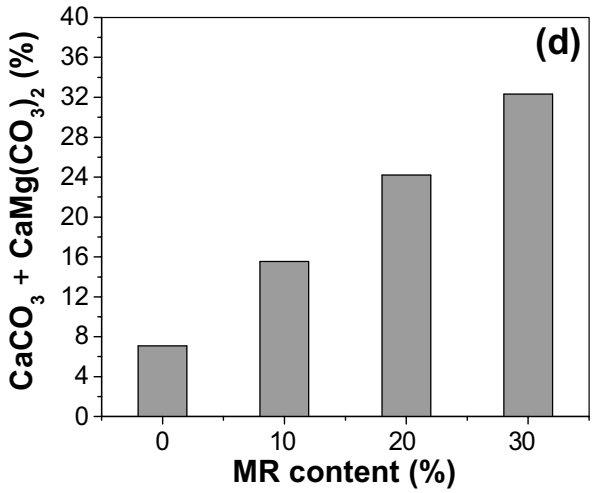


Table 6 Nominal and experimental contents of carbonates in the cement pastes containing marble residues

\begin{tabular}{lllllll}
\hline Paste (\%) & Nominal content & & & & Experimental content & \\
\cline { 2 - 3 } & MR & PC & Total & & MR & Total \\
& $\% \mathrm{CaCO}_{3}+\% \mathrm{MgCa}\left(\mathrm{CO}_{3}\right)_{2}$ & $\% \mathrm{CaCO}_{3}$ & & & $\% \mathrm{CaCO}_{3}+\% \mathrm{MgCa}\left(\mathrm{CO}_{3}\right)_{2}$ & \\
\hline 10 & 9.36 & 6.37 & 15.73 & 9.19 & 15.56 \\
20 & 18.73 & 5.66 & 24.39 & 18.53 & 24.19 \\
30 & 28.09 & 4.96 & 33.05 & & 27.36 & 32.32 \\
\hline
\end{tabular}

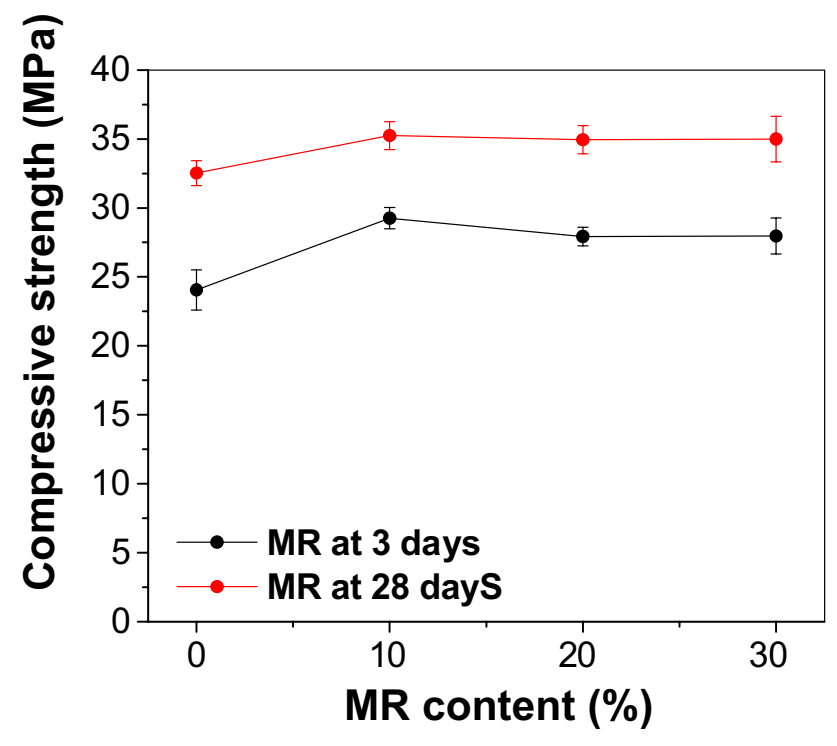

Fig. 7 Axial compression strength tests of the pastes containing different replacements of marble residue

\subsection{Influence of MR on axial compressive strength of the cement pastes}

The results of axial compression strength tests of the pastes containing different replacements of marble residue, at the ages of 3 and 28 days of cure, are presented in Fig. 7.

Similar behaviors were observed for the pastes cured for 3 and 28 days, and no significant compressive strength variation was observed for the pastes containing 20 and $30 \% \mathrm{MR}$, as compared to the paste containing $10 \%$ replacement. Figure 7 shows that there was an increase in the axial compressive strength with the addition of the marble residue to the paste, as compared to the pure cement paste. Such increase was quite significant and, considering that marble did not play a role in the hydration process, this may be assigned to the marble residue grain size heterogeneity, shown in Table 3. Thus, although the fraction of smaller particles of marble $(<75 \mu \mathrm{m})$ could have provided a minor porefilling or micro-filler effect, the heterogeneously sized

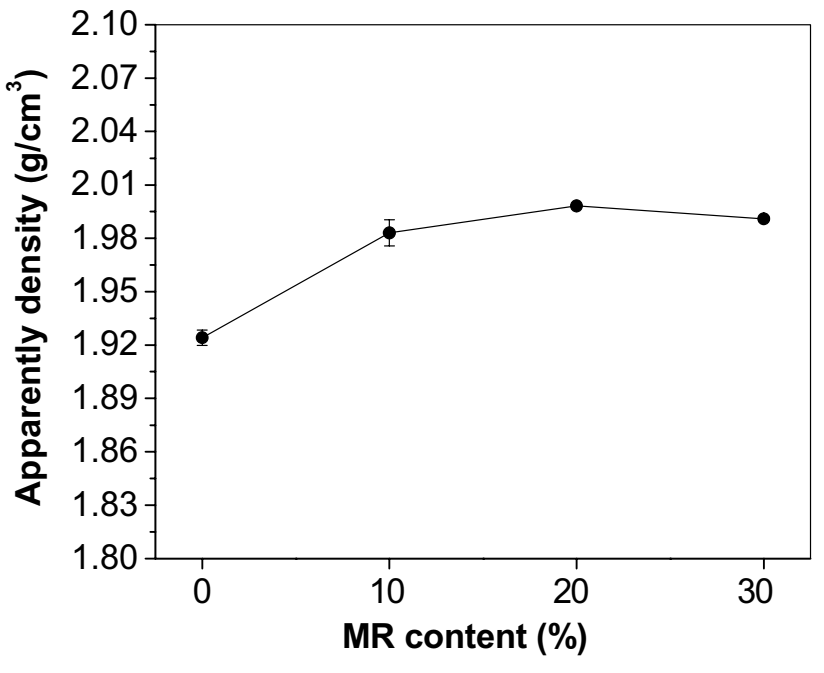

Fig. 8 Apparent densities of the pastes produced with marble residue

marble particles acted as major packing agent, leading to a more compact and dense material.

Therefore, the marble residue acted as an inert addition, by physically reducing the porosity and improving the microstructure and the property of the matrix transition zone, due to an efficient particle packing [47].

\subsection{Influence of MR on the physical properties of hardened cement paste}

To confirm the last assumptions, the apparent densities of the pastes containing MR are shown in Fig. 8.

The apparent density of the pastes increased and then stabilized with the increase in MR content of the paste, indicating that the residue promoted a better packing in the cementitious matrix, reducing the number of voids. These results were consistent with the results of compressive strength, since the tendency of the compressive strength is to increase with the increase in the bulk density.

The water capillary absorption as a function of the test time and total water absorption as a function of marble residue content are shown in Fig. 9. 
Since the absorption by capillarity depends on the porosity of the matrix and the interconnectivity of the pores, Fig. 9a shows that the absorption rate decreased with the addition of the marble residue. The limited water penetration in the pores is assigned to the refinement of the pore structures, provided by the residue. Such refinement promoted the formation of smaller or less continuous pores.

As the capillary absorption mechanism is one of the means of water entering the matrix, the transport of fluids, liquid or gas has a significant contribution to its deterioration and is therefore a determining factor for durability of material. In this way, it can be inferred that the addition of
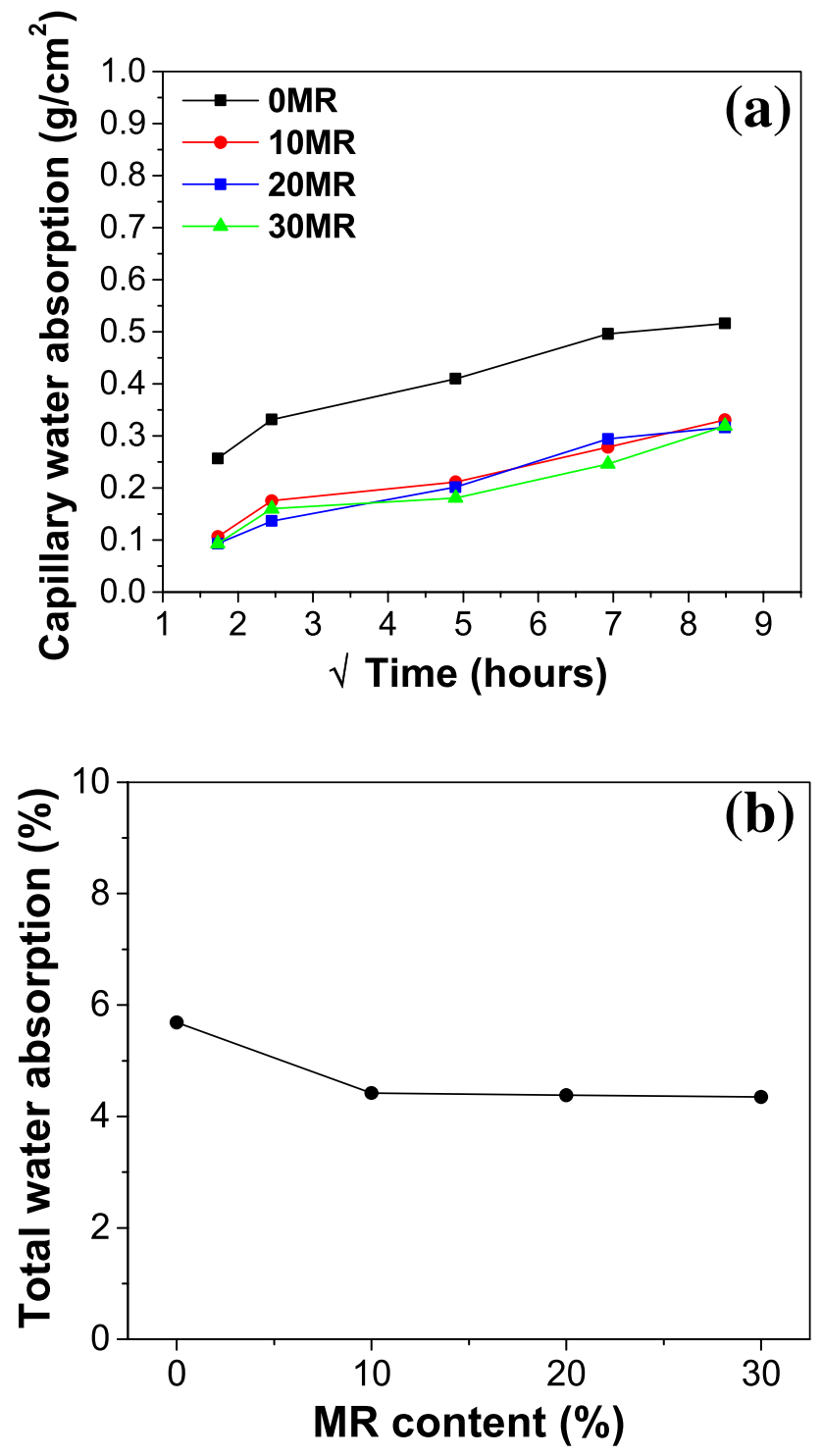

Fig. 9 a Capillary absorption of water and $\mathbf{b}$ total absorption of water by cement pastes containing marble residue
MR to the pastes promoted an improvement in the durability of the matrix in all the studied contents.

\subsection{Reduction of $\mathrm{CO}_{2}$ emissions in the cement industry due to the use of MR as partial substitute}

Considering that the production of Portland cement in Brazil attained 53 million tons in 2018 [48] and that the production of cement $C P V$ represents about $8 \%$ of the total cement production [49], the production of CP V in 2018 corresponded to 4.2 million ton. Consequently, the $\mathrm{CO}_{2}$ emission related to the limestone calcination process for the manufacture of the CP V cement, in 2018, was calculated as 1.7 million tons. Similarly, the $\mathrm{CO}_{2}$ emission related to the energy consumption in the in the production of Portland cement attained 13.8 million tons in 2018, corresponding to 1.1 million tons of $\mathrm{CO}_{2}$ emitted in 2018 due to production of CP V cement.

Thus, by adding the $\mathrm{CO}_{2}$ emissions related to limestone calcination to that related to energy consumption according to Eq. 5, the total emission due to the production of the CP V cement in 2018 was calculated as 2.8 million tons of $\mathrm{CO}_{2}$, corresponding to an emission factor of about 0.66 ton of $\mathrm{CO}_{2}$ per ton of cement.

In 2018, 2.1 million tons of marble was produced in Brazil [33]. Taking into account that about $30 \%$ of the processed material is discarded, the amount of marble residue achieved 0.63 million ton and this represents about $14 \%$ of the CP V cement production in Brazil. The results presented herein indicated that the marble residue may be successfully used as a replacement material. Thus, the replacement of $10 \%$ cement for marble residue in a cement matrix would correspond to a reduction of 0.28 million tons of $\mathrm{CO}_{2}$ million tons in the production of the cement $\mathrm{CP} \mathrm{V}$.

Despite the peculiar energetic matrix due to the major use of hydroelectric power in Brazil, this is a developing country and there is an increasing demand for cement and construction materials. Consequently, the development of sustainable cementitious materials with lower $\mathrm{CO}_{2}$ emissions meets the Paris COP21 [50] resolution to reduce the greenhouse gases related to the climate changes. On the other hand, since GHG mitigation projects generate carbon credits [51], this approach can be also used to support the development of the necessary infrastructure of the country.

\section{Conclusions}

The marble residue acted as a non-reactive replacement material that presented only physical and mechanical effects when added to the cement pastes. 
However, in practice, due the more heterogeneous fineness of the as received granular residue, the larger particles provided an efficient packing effect while the finer particles could provide with some filler action. Thus, the partial replacement of cement by the granular marble residue provided the refinement of the matrix pores, increasing the density of the cement paste and consequently contributing to increase the durability of the paste.

A reduction of 0.28 million tons of $\mathrm{CO}_{2}$ was calculated for the addition of $10 \%$ marble residue in the production of the cement CPV.

In this frame, the results presented herein indicate an alternative means to reduce the $\mathrm{CO}_{2}$ emissions in the cement industry and to reuse the marble residue that would otherwise be inadequately disposed.

Acknowledgements H.M.C.A. (Proc. Nr. 305112/2015) and J.P.G. acknowledge National Counsel of Technological and Scientific Development (CNPq) for their Research Grant.

Funding This research did not receive any specific grant from funding agencies, commercial or not-for-profit sectors.

\section{Compliance with ethical standards}

Conflict of interest On behalf of all authors, the corresponding author states that there is no conflict of interest.

\section{References}

1. Intergovernmental Panel on Climate Change (2007) Fourth assessment report: climate change 2007: synthesis report. Summary for policymakers. https://www.ipcc.ch/report/ar4/ syr/. Accessed 4 Oct 2018

2. Cement Sustainability Initiative (2018) $\mathrm{CO}_{2}$ and climate protection. World Business Council for Sustainable Development (WBCSD). https://www.wbcsdcement.org/. Accessed 4 Oct 2018

3. Aliabdo AA, Abd Elmoaty AE, Auda EM (2014) Re-use of waste marble dust in the production of cement and concrete. Constr Build Mater 50:28-41. https://doi.org/10.1016/j.conbuildma t.2013.09.005

4. Marmol I, Ballester P, Cerro S, Monros G, Morales J, Sanchez L (2010) Use of granite sludge wastes for the production of coloured cement-based mortars. Cem Concr Comp 32:617-622. https://doi.org/10.1016/j.cemconcomp.2010.06.003

5. De Belie N, Soutsos M, Gruyaert E (2018) Properties of fresh and hardened concrete containing supplementary cementitious materials: state-of-the-art report of the RILEM Technical Committee 238-SCM working group 4. Springer, Cham

6. de Souza LGM, Santos NR, Cavalcante AG, de Souza L, Costa LCF (2017) Composite utilizing residues of marble and granite for building popular homes. J Build Eng 9:192-197. https://doi. org/10.1016/j.jobe.2017.01.003

7. Abd Elmoaty AEM (2013) Mechanical properties and corrosion resistance of concrete modified with granite dust. Constr Build Mater 47:743-752. https://doi.org/10.1016/j.conbuildma t.2013.05.054

8. Singh M, Srivastava A, Bhunia D (2017) An investigation on effect of partial replacement of cement by waste marble slurry. Constr
Build Mater 134:471-488. https://doi.org/10.1016/j.conbuildma t.2016.12.155

9. Singh S, Nagar R, Agrawal V (2016) Performance of granite cutting waste concrete under adverse exposure conditions. J Clean Prod 127:172-182. https://doi.org/10.1016/j.jclepro.2016.04.034

10. Ministério das Minas e Energia (2009) Perfil de Rochas Ornamentais e de Revestimento. www.mme.gov.br/. Accessed 4 Oct 2018

11. Ashish DK (2018) Feasibility of waste marble powder in concrete as partial substitution of cement and sand amalgam for sustainable growth. J Build Eng 15:236-242. https://doi.org/10.1016/j. jobe.2017.11.024

12. Li LG, Huang ZH, Tan YP, Kwan AKH, Liu F (2018) Use of marble dust as paste replacement for recycling waste and improving durability and dimensional stability of mortar. Constr Build Mater 166:423-432. https://doi.org/10.1016/j.conbuildma t.2018.01.15

13. Seghir NT, Mellas M, Sadowski L, Zak A (2018) Effects of marble powder on the properties of the air-cured blended cement paste. J Clean Prod 183:858-868. https://doi.org/10.1016/j.jclep ro.2018.01.267

14. Erguen A (2011) Effects of the usage of diatomite and waste marble powder as partial replacement of cement on the mechanical properties of concrete. Constr Build Mater 25:806-812. https:// doi.org/10.1016/j.conbuildmat.2010.07.002

15. Kurdowski W (2014) Cement and concrete chemistry. Springer, Dordrecht

16. Uysal M, Sumer M (2011) Performance of self-compacting concrete containing different mineral admixtures. Constr Build Mater 25:4112-4120. https://doi.org/10.1016/j.conbuildma t.2011.04.032

17. Taylor HFW (1990) Cement chemistry. Academic Press, Londres

18. Matschei T, Lothenbach B, Glasser FP (2007) The role of calcium carbonate in cement hydration. Cem Concr Res 37:551-558. https://doi.org/10.1016/j.cemconres.2006.10.013

19. ABNT NBR 5733 (1991) Initial high strength Portland cement (in Portuguese)

20. ASTM C150 (2019) Standard specification for Portland cement

21. ASTM E300-03 (2017) Standard practice for sampling industrial

22. ASTM C39 (2018) Standard test method for compressive strength of cylindrical concrete specimens

23. Bogue RH (1947) The chemistry of Portland cement, 1st edn. Reinhold Publishing Corporation, New York

24. ASTM D6913 (2017) Standard test methods for particle-size distribution (gradation) of soils using sieve analysis

25. Dweck J, Cherem da Cunha AL, Pinto CA, Goncalves JP, Buechler PM (2009) Thermogravimetry on calcined mass basis: hydrated cement phases and pozzolanic activity quantitative analysis. J Therm Anal Calorim 97(1):85-89. https://doi.org/10.1007/s1097 3-008-9761-0

26. ASTM C127-15 (2015) Standard test method for relative density (specific gravity) and absorption of coarse aggregate

27. ASTM C1585-04 (2014) Standard test method for measurement of rate of absorption of water by hydraulic-cement concretes

28. ASTM C642-13 (2013) Standard test method for density, absorption, and voids in hardened concrete

29. Intergovernmental Panel on Climate Change (IPCC) Guidelines for National Greenhouse Gas Inventories, OECD/IEA (2006). https://www.ipcc-nggip.iges.or.jp/public/2006gl/. Accessed 4 May 2020

30. Intergovernmental Panel on Climate Change (2000) Good practice guidance and uncertainty management in national greenhouse gas inventories. https://www.ipcc-nggip.iges.or.jp/publi c/gp/english/

31. Tolmasquim MT, Szklo AS (2000) The Brazilian energetic matrix at the turn of the millennium. ENERGE COPPE/UFRJ, Rio de Janeiro (in Portuguese) 
32. Ministério das Minas e Energia (MME) (2019) National energy balance. http://www.epe.gov.br/pt/publicacoes-dados-abert os/publicacoes/balanco-energetico-nacional-2019. Accessed 4 May 2020

33. Associação Brasileira da Indústria de Rochas Ornamentais (2018) The Brazilian sector of ornamental rocks. http://abirochas.com. br/wp-content/uploads/2018/06/abinoticias/Setor_de_Rocha s_Ornamentais.pdf/. Accessed 4 May 2020

34. ASTM C618-19 (2019) Standard specification for coal fly ash and raw or calcined natural pozzolan for use in concrete

35. Çelic T, Marar K (1996) Effects of crushed stone dust on some properties of concrete. Cem Concr Res 26:1121-1130. https:// doi.org/10.1016/0008-8846(96)00078-6

36. Siddique R, Cachim P (2018) Waste and supplementary cementitious materials in concrete: characterisation. Properties and applications. Elsevier, Cambridge

37. Petrucci EGR (1998) Concreto de Cimento Portland. Globo, São Paulo

38. Buyuksagis IS, Uygunoglu T, Tatar E (2017) Investigation on the usage of waste marble powder in cement-based adhesive mortar. Constr Build Mater 154:734-742. https://doi.org/10.1016/j. conbuildmat.2017.08.014

39. Wenk HR (1976) Electron microscopy in mineralogy. Springer, Berlin

40. Pacewska B, Wilinska I, Bukowska M (2000) Hydration of cement slurry in the presence of spent cracking catalyst. J Therm Anal Calorim 60(1):71-78. https://doi.org/10.1023/a:1010120518062

41. Pinto CA, Buchler PM, Dweck J (2007) Pozzolanic properties of a residual FCC catalyst during the early stages of cement hydration. J Therm Anal Calorim 87(3):715-720. https://doi. org/10.1007/s10973-006-7772-2

42. Santos Silva FG, Fiuza Junior RA, da Silva JS, de Brito CMSR, Carvalho Andrade HM, Goncalves JP (2013) Consumption of calcium hydroxide and formation of $\mathrm{C}-\mathrm{S}-\mathrm{H}$ in cement pastes. J Therm Anal Calorim 116(1):287-293. https://doi.org/10.1007/ s10973-013-3546-9

43. Wongkeo $\mathrm{W}$, Thongsanitgarn $\mathrm{P}$, Chindaprasirt $\mathrm{P}$, Chaipanich $\mathrm{A}$ (2013) Thermogravimetry of ternary cement blends. J Therm
Anal Calorim 113(3):1079-1090. https://doi.org/10.1007/s1097 3-013-3017-3

44. El-Gamal SM, Hashem FS (2017) Enhancing the thermal resistance and mechanical properties of hardened Portland cement pastes using pumice and $\mathrm{Al}_{2} \mathrm{O}_{3}$. J Therm Anal Calorim 128(1):1527. https://doi.org/10.1007/s10973-016-5863-2

45. El-Gamal SM, Abo-El-Enein SA, El-Hosiny FI, Amin MS, Ramadan M (2017) Thermal resistance, microstructure and mechanical properties of type I Portland cement pastes containing low cost nano particles. J Therm Anal Calorim 131(2):949-968. https ://doi.org/10.1007/s10973-017-6629-1

46. Ramadan M, El-Gamal SM, Selim FA (2020) Mechanical properties, radiation mitigation and fire resistance of OPC-recycled glass powder composites containing nanoparticles. Constr Build Mater 251:118703. https://doi.org/10.1016/j.conbuildma t.2020.118703

47. Prošek Z, Nežerka V, Tesárek $P$ (2020) Enhancing cementitious pastes with waste marble sludge. Constr Build Mater 255:1 19372

48. U.S. Geological Survey (2020) Mineral commodity summaries. https://www.usgs.gov/centers/nmic/mineral-commoditysummaries. Accessed 4 May 2020

49. Sindicato Nacional da Indústria de Cimento (SNIC) (2013) Annual report. [cited 2018 Oct 04]. http://snic.org.br/

50. United Nations Framework Convention on Climate Change (UNFCCC) (2015) COP21. [cited 2018 Nov 19]. https://unfccc.int/

51. Godoy SGM, Saes MSM (2015) Cap-and-trade and projectbased framework: how do carbon markets work for greenhouse emissions reduction? Ambient Soc 18(1):135-154. https://doi. org/10.1590/1809-4422ASOC795V1812015en

Publisher's Note Springer Nature remains neutral with regard to jurisdictional claims in published maps and institutional affiliations. 